\title{
Evaluation of Science Teachers' Knowledge towards Mumps Disease in Primary Schools
}

\author{
Haqi I. Mansoor ${ }^{1}$, Kahtan H. Hussein ${ }^{2}$ \\ ${ }^{1}$ Assistant Lecturer, College of Nursing, University of Kerbala, Iraq, \\ ${ }^{2}$ Professor, College of Nursing, University of Babylon, Iraq
}

\begin{abstract}
A descriptive study has been used the evaluating science teachers' knowledge towards mumps disease in primary schools. A probability (simple random sample) the sample consisted of 60 science teachers from 60 primary schools in Holy Kerbala city, during the period of January 2018 to the end of June 2019. The questionnaire involved two-part: the first, demographic data of teachers such as age, gender, and specialization, level of education, years of employment, participation in training course or workshop toward communicable diseases and second part, concerning teachers' knowledge about mumps in primary schools were comprised of (36) items divided to (6) items related to knowledge about anatomy and physiological of salivary glands, general knowledge about mumps (5) items, knowledge about signs and symptoms of mumps disease (7) items, knowledge about diagnosis and complications of mumps disease (6) items, knowledge about mode of transmission for mumps infection (6) items, knowledge about prevention and treatment of mumps disease. The data was collected by a questionnaire which consisted of two parts, the first part consists socio-demographic data, second part was about the knowledge of mumps disease which consist of (36) items scale of knowledge about mumps disease. In the present study, data were analyzed through the use of statistical package for social sciences (SPSS), version 24. The finding of the study indicated that most of the teachers who participated in the study were female, most of them graduated from institutes and they have an extremely low level of knowledge toward mumps ranges between poor and fair. The study recommends encouraging teachers' participation in the health education program, especially programs that deal with communicable diseases because the risk of spread these diseases among the school community.
\end{abstract}

Keywords: Evaluation, Science Teachers, Knowledge, Mumps, Primary Schools.

\section{Introduction}

Mumps virus can infect the children and adults at the same time. This virus is spread when an infected person talks, coughs or sneezes small droplets containing infectious agents into the air. The droplets in the air may be breathed in by those nearby. Infection may be spread by contact with hands, tissues and other articles soiled by the infected nose and throat discharges. Mumps virus is also spread by direct contact with the saliva of an infected person ${ }^{1}$. The crowded places such as schools considered high risk to spreading mumps. Many schools was closed because lack of control on the spread of the disease. Mumps was most commonly reported among young school-age children ${ }^{2}$. the schools consider a vital aspect of pupils' health because teachers who can spend time in the classroom occasionally are more aware of the details of their child's day. When increasing the knowledge of primary school teachers toward the signs and symptoms of mumps, the complications of the disease and how to deal with infected children will help in the early diagnosis of the disease and transfer the infected patient to the hospital as soon as possible therefore decreasing the spread of the disease among the rest of the students. So, the teachers need to play a major role in the health aspect of school children ${ }^{3}$. School health is effective in helping students achieve their health literacy, enhance their health-related behaviors, and thereby improve their health status. However, in resource-limited countries, evidence is limited to show the impact of school health ${ }^{4}$. Health Promoting School (HPS) strives to make school a positive experience for pupils, staff, and visitors by 
paying special attention to all aspects of health in every area of the school. The whole school community takes action and places priority on creating an environment that will have the best possible impact on the health and learning of pupils, staff, and parents ${ }^{5}$.

\section{Methodology}

A descriptive study has been used the evaluating science teachers' knowledge towards mumps disease in primary schools. A probability (simple random sample) the sample consisted of 60 science teachers from 60 primary schools in Holy Kerbala city, during the period of January 2018 to the end of June 2019. The questionnaire has been constructed according to the review of the related literature about mumps was used for data collection. The content validity has been determined through the panel of 17 experts their specialties fields are nursing and medicine. and its reliability was estimated through a pilot study conducted in (10) schools is excluded from the original sample which included (10) primary school teachers. Thereliability of the questionnaire is determined through the use of pre-posttest technique and computing of correlation coefficients $(r=0.93)$. The questionnaire involved two-part: the first, demographic data of teachers such as age, gender, and specialization, level of education, years of employment, participation in training course or workshop toward communicable diseases and second part, concerning teachers' knowledge about mumps in primary schools were comprised of (36) items divided to (6) items related to knowledge about anatomy and physiological of salivary glands, general knowledge about mumps (5) items, knowledge about signs and symptoms of mumps disease (7) items, knowledge about diagnosis and complications of mumps disease (6) items, knowledge about mode of transmission for mumps infection (6) items, knowledge about prevention and treatment of mumps disease. The questionnaire was submitted to the teachers for the evaluating their knowledge about mumps disease. Ranging and scoring of study used the triple Likert scale was used for the purpose of items' rating which are scored as follows: yes $=1$, uncertain $=2$ and no $=$ 3. The level of overall knowledge was estimated by calculating the mean of score and the cutoff point for the total score of knowledge as follow: poor knowledge (36 $-60)$, fair knowledge $(61-84)$, and good knowledge ( 85 - 108). The level of knowledge for sub-domain was also estimated by calculating the mean of score and the cutoff point for the total score of sub-domain knowledge as follow: the sub-domains of "anatomy and physiology, diagnosis and complications of mumps, mumps' mode of transmission, and prevention of mumps" were scored as follow: poor knowledge $(1-1.66)$, fair knowledge $(1.67-2.33)$, and good knowledge $(2.34-3)$.the data of the study were analyzed through the use of Statistical Package for Social Science Program (IBM SPSS) version 2424 through a statistical approach that includes (frequency, percentage, Mean of score (M.S.) and standard deviation (SD).

\section{Results and Discussion}

Table (1) indicates that the level of overall teachers' knowledge toward mumps $(47.2 \%)$ for both level poor and fair that reflect a clear decreasing in levels of knowledge about mumps. The study used variables for the first time and there are no studies to support the findings. in the following paragraphs, the teachers' knowledge about mumps disease will be discussed for each of the following items, the anatomy and physiology, general information about mumps, symptoms and symptoms of mumps, diagnosis and complications of mumps, mode of transmission and finally the prevention and treatment of mumps. The evaluation of teachers' Knowledge toward mumps for each item of (table 2) which have six-part (A,B,C,D,E and F), A ' knowledge related to anatomy and physiology of salivary glands " this part reveals that teachers among study group are showing fair level of knowledge regarding the item 1, 2 , and poor level regarding remaining items of 3,4 , and 5 except item 6 the mean of score indicate good levels. $B$ " teachers' knowledge about general information of mumps " this part depicts those teachers among the study group showing fair level of knowledge among all items of general knowledge domain except item 5 that show good level. C " teachers' knowledge about symptoms and signs of mumps " this part indicates that the mean of scores of all items were a poor so there are clear decrease in the level of knowledge regard signs and symptoms of mumps. D " knowledge about diagnosis and complications of mumps " this part indicates poor level among all items except item 4 which are fair. E " knowledge about mode of transmission of mumps " this part reveals among study group teachers are showing fair level of knowledge among all items except item 5 that reflects good level. F "' evaluation of teachers' knowledge about prevention and treatment of mumps", This part reveals fair level of knowledge in items 1, 2, 5, and poor level in items 3, 4, and 6 . 
Table (1): Overall Evaluation of Teachers' Knowledge toward Mumps disease

\begin{tabular}{|c|c|c|c|c|c|c|}
\hline No. & Levels of Knowledge & Frequency & Percent & Cumulative Percent & M.S & S.D \\
\hline 1 & Poor & 17 & 47.2 & 47.2 & \multirow{4}{*}{1.58} & \multirow{4}{*}{.60} \\
\hline 2 & Fair & 17 & 47.2 & 94.4 & & \\
\hline 3 & Good & 2 & 5.6 & 100.0 & & \\
\hline & Total & 30 & 100 & & & \\
\hline
\end{tabular}

M.S: Mean of score, SD Standard deviation, Poor $=36-60$, Fair $=61-84$, Good $=85-108$

Table (2): Evaluation of Teachers' Knowledge toward Mumps disease

\begin{tabular}{|c|c|c|c|c|c|c|c|c|c|}
\hline \multirow{2}{*}{$\mathbf{A}$} & \multirow{2}{*}{ Knowledge related to Anatomy and Physiology } & \multicolumn{2}{|c|}{ Yes } & \multicolumn{2}{|c|}{ Not sure } & \multicolumn{2}{|c|}{ No } & \multirow{2}{*}{ M.S } & \multirow{2}{*}{ Level } \\
\hline & & $\mathbf{F}$ & $\%$ & $\mathbf{F}$ & $\%$ & $\mathbf{F}$ & $\%$ & & \\
\hline 1 & $\begin{array}{l}\text { Salivary glands include two types of glands: parotid and } \\
\text { subcutaneous glands only. }\end{array}$ & 21 & 35 & 21 & 35 & 18 & 30 & 1.95 & Fair \\
\hline 2 & The parotid gland is the smallest salivary glands. & 16 & 26.7 & 31 & 51.7 & 13 & 21.7 & 1.95 & Fair \\
\hline 3 & $\begin{array}{l}\text { The parotid gland does not secrete saliva but has a key role in } \\
\text { enhancing immunity. }\end{array}$ & 45 & 75 & 12 & 20 & 3 & 5 & 1.3 & Poor \\
\hline 4 & $\begin{array}{l}\text { The parotid gland is located under the lower jaw and under the } \\
\text { tongue. }\end{array}$ & 42 & 70 & 6 & 10 & 12 & 20 & 1.5 & Poor \\
\hline 5 & $\begin{array}{l}\text { Some cases of mumps spread swelling to the chest and cause } \\
\text { health problems. }\end{array}$ & 31 & 51.7 & 20 & 33.3 & 9 & 15 & 1.63 & Poor \\
\hline 6 & $\begin{array}{l}\text { In mumps, there is no possibility that the rest of the lymphatic } \\
\text { system will be affected. }\end{array}$ & 18 & 30 & 14 & 23.3 & 28 & 46.7 & 2.16 & Good \\
\hline \multirow{2}{*}{ B } & \multirow{2}{*}{ General Knowledge about Mumps } & \multicolumn{2}{|c|}{ Yes } & \multicolumn{2}{|c|}{ Not sure } & \multicolumn{2}{|c|}{ No } & \multirow{2}{*}{ M.S } & \multirow{2}{*}{ Level } \\
\hline & & $\mathbf{F}$ & $\%$ & $\mathbf{F}$ & $\%$ & $\mathbf{F}$ & $\%$ & & \\
\hline 1 & A bacterial disease caused by bacteria called mumps. & 34 & 56.7 & 11 & 18.3 & 15 & 25 & 1.68 & Fair \\
\hline 2 & $\begin{array}{l}\text { Age is not considered a risk factor. All ages have the same } \\
\text { chance of infection. }\end{array}$ & 34 & 58.3 & 2 & 3.3 & 23 & 38.3 & 1.8 & Fair \\
\hline 3 & Taking some medications do not affect the rate of infection. & 15 & 26.7 & 29 & 48.3 & 15 & 25 & 1.98 & Fair \\
\hline 4 & $\begin{array}{l}\text { The particles of mumps live within particular organs (e.g. } \\
\text { parotid glands), do not spread to other organs through blood } \\
\text { circulation or lymphatic systems. }\end{array}$ & 31 & 51.7 & 14 & 23.3 & 15 & 25 & 1.73 & Fair \\
\hline 5 & There is no need to isolate the patient with mumps. & 6 & 10 & 6 & 10 & 48 & 80 & 2.7 & Good \\
\hline \multirow{2}{*}{ C } & \multirow{2}{*}{ Knowledge about Symptoms and Signs } & \multicolumn{2}{|c|}{ Yes } & \multicolumn{2}{|c|}{ Not sure } & \multicolumn{2}{|c|}{ No } & \multirow{2}{*}{ M.S } & \multirow{2}{*}{ Level } \\
\hline & & $\mathbf{F}$ & $\%$ & $\mathbf{F}$ & $\%$ & $\mathbf{F}$ & $\%$ & & \\
\hline 1 & $\begin{array}{l}\text { Mumps causes swelling and pains in the salivary glands that } \\
\text { located at the upper side of the jaw in front of the ear. }\end{array}$ & 56 & 93.3 & 2 & 3.3 & 2 & 3.3 & 1.1 & Poor \\
\hline 2 & $\begin{array}{l}\text { All patients with mumps have symptoms of swelling in the } \\
\text { parotid glands. }\end{array}$ & 48 & 80 & 6 & 10 & 6 & 10 & 1.3 & Poor \\
\hline 3 & $\begin{array}{l}\text { Initial signs and symptoms include painful swelling of one or } \\
\text { both of the parotid glands. }\end{array}$ & 55 & 91.7 & 4 & 6.7 & 1 & 1.7 & 1.1 & Poor \\
\hline 4 & $\begin{array}{l}\text { The symptoms generally occur between the two days 5-7 days } \\
\text { after exposure. }\end{array}$ & 39 & 65 & 17 & 28.3 & 4 & 6.7 & 1.41 & Poor \\
\hline 5 & Symptoms disappear 7 to 10 days after infection. & 34 & 56.7 & 16 & 26.7 & 10 & 16.7 & 1.6 & Poor \\
\hline 6 & $\begin{array}{l}\text { The person becomes infectious after several days of onset of } \\
\text { symptoms and not considered infectious before the onset of } \\
\text { symptoms. }\end{array}$ & 38 & 63.3 & 11 & 18.3 & 11 & 18.3 & 1.55 & Poor \\
\hline 7 & Symptoms are more severe in children than adults. & 44 & 73.3 & 6 & 10 & 10 & 16.7 & 1.43 & Poor \\
\hline
\end{tabular}




\begin{tabular}{|c|c|c|c|c|c|c|c|c|c|}
\hline \multirow{2}{*}{ D } & \multirow{2}{*}{ Knowledge about Diagnosis and Complications } & \multicolumn{2}{|c|}{ Yes } & \multicolumn{2}{|c|}{ Not sure } & \multicolumn{2}{|c|}{ No } & \multirow{2}{*}{ M.S } & \multirow{2}{*}{ Level } \\
\hline & & $\mathbf{F}$ & $\%$ & $\mathbf{F}$ & $\%$ & $\mathbf{F}$ & $\%$ & & \\
\hline 1 & $\begin{array}{l}\text { One condition for the diagnosis of mumps is the presence of } \\
\text { symptoms. }\end{array}$ & 51 & 85 & 2 & 3.3 & 7 & 11.7 & 1.26 & Poor \\
\hline 2 & $\begin{array}{l}\text { When there is swelling in the parotid gland, the diagnosis } \\
\text { is mumps and can be confirmed by palpation the sublingual } \\
\text { glands. }\end{array}$ & 37 & 61.7 & 18 & 30 & 5 & 8.3 & 1.46 & Poor \\
\hline 3 & $\begin{array}{l}\text { Blood test for antibodies (IgM) provides a final result of the } \\
\text { diagnosis. }\end{array}$ & 32 & 53.3 & 27 & 45 & 1 & 1.7 & 1.48 & Poor \\
\hline 4 & $\begin{array}{l}\text { Meningitis of the brain is not considered a complication of } \\
\text { mumps. }\end{array}$ & 22 & 36.7 & 25 & 41.7 & 13 & 21.7 & 1.85 & Fair \\
\hline 5 & $\begin{array}{l}\text { Possible to swelling in the ovarian or testicles in equal } \\
\text { proportions. }\end{array}$ & 32 & 53.3 & 23 & 38.3 & 5 & 8.3 & 1.55 & Poor \\
\hline 6 & The rate of infertility in female more than male. & 24 & 40 & 18 & 30 & 18 & 30 & 1.9 & Poor \\
\hline \multirow{2}{*}{$\mathbf{E}$} & \multirow{2}{*}{ Knowledge about Mode of Transmission } & \multicolumn{2}{|c|}{ Yes } & \multicolumn{2}{|c|}{ Not sure } & \multicolumn{2}{|c|}{ No } & \multirow{2}{*}{ M.S } & \multirow{2}{*}{ Level } \\
\hline & & $\mathbf{F}$ & $\%$ & $\mathbf{F}$ & $\%$ & $\mathbf{F}$ & $\%$ & & \\
\hline 1 & $\begin{array}{l}\text { Mumps infection can be controlled because it is a slow spread } \\
\text { among people. }\end{array}$ & 32 & 53 & 9 & 15 & 19 & 31.7 & 1.78 & Fair \\
\hline 2 & $\begin{array}{l}\text { Mumps infection spreads in winter; spring, autumn and } \\
\text { summer alike. }\end{array}$ & 30 & 50 & 9 & 15 & 21 & 35 & 1.85 & Fair \\
\hline 3 & $\begin{array}{l}\text { Mumps is transmitted from person to person and can be } \\
\text { transmitted from animal to human. }\end{array}$ & 28 & 46.7 & 22 & 36.7 & 10 & 16.7 & 1.7 & Fair \\
\hline 4 & Human is not considered the only natural host to mumps. & 20 & 33.3 & 28 & 46.7 & 12 & 20 & 1.86 & Fair \\
\hline 5 & $\begin{array}{l}\text { Mumps infection is not transmitted through the saliva of an } \\
\text { infected person that sprays in the air. }\end{array}$ & 15 & 25 & 6 & 10 & 39 & 65 & 2.4 & Good \\
\hline 6 & $\begin{array}{l}\text { Mumps virus cannot survive on surfaces, so contact with } \\
\text { infected objects is not considered dangerous. }\end{array}$ & 18 & 30 & 14 & 23.3 & 28 & 46.7 & 2.16 & Fair \\
\hline \multirow{2}{*}{$\mathbf{F}$} & \multirow{2}{*}{ Knowledge about Prevention and Treatment } & \multicolumn{2}{|c|}{ Yes } & \multicolumn{2}{|c|}{ Not sure } & \multicolumn{2}{|c|}{ No } & \multirow{2}{*}{ M.S } & \multirow{2}{*}{ Level } \\
\hline & & $\mathbf{F}$ & $\%$ & $\mathbf{F}$ & $\%$ & $\mathbf{F}$ & $\%$ & & \\
\hline 1 & $\begin{array}{l}\text { After the infected with mumps disease, the person has not } \\
\text { acquired immunity against the disease for life. }\end{array}$ & 23 & 38.3 & 7 & 11.7 & 30 & 50 & 2.11 & Fair \\
\hline 2 & $\begin{array}{l}\text { There is a high probability of recurrent infection of mumps in } \\
\text { a previously infected person. }\end{array}$ & 18 & 30 & 12 & 20 & 30 & 50 & 2.2 & Fair \\
\hline 3 & $\begin{array}{l}\text { Mumps can be prevented by taking four doses of mumps } \\
\text { vaccine. }\end{array}$ & 31 & 51.7 & 27 & 45 & 2 & 3.3 & 1.51 & Poor \\
\hline 4 & $\begin{array}{l}\text { Mumps vaccine is often given alone and is not combined with } \\
\text { another vaccine. }\end{array}$ & 33 & 55 & 23 & 38.3 & 4 & 6.7 & 1.51 & Poor \\
\hline 5 & $\begin{array}{l}\text { The availability of mumps vaccine is not an important factor } \\
\text { that effects on rates of infection. }\end{array}$ & 16 & 26.7 & 14 & 23.3 & 30 & 50 & 2.23 & Fair \\
\hline 6 & $\begin{array}{l}\text { There is a specific treatment for mumps that can be given for } \\
\text { cure from disease. }\end{array}$ & 44 & 73 & 5 & 8.3 & 11 & 18.3 & 1.45 & Poor \\
\hline
\end{tabular}

M.S: Mean of score, Poor $=1-1.66$, Fair $=1.67-2.33$, Good $=2.34-3$

\section{Conclusion}

The finding of the study indicated that most of the teachers who participated in the study were female, most of them graduated from institutes and they have an extremely low level of knowledge toward mumps ranges between poor and fair level of knowledge. The study recommends encouraging teachers' participation in the health education program, especially programs that deal with communicable diseases because of the risk of spreading these diseases among the school community. Emphasis on future studies could be done to evaluation teachers' knowledge relating to other communicable 
diseases at the primary schools. Hence, increase the awareness of the school community's awareness about these diseases.

Financial Disclosure: There is no financial disclosure.

Conflict of Interest: None to declare.

Ethical Clearance: All experimental protocols were approved under the Faculty of Nursing, University of Baghdad. Iraq and all experiments were carried out in accordance with approved guidelines.

\section{References}

1. Australia Ministry of Health. Notifiable conditions. the law requires doctors and laboratories to report some infections or diseases to SA Health. 2018; available in: https://www.sahealth.sa.gov.au.

2. Orenstein, W.A., Offit, P.A., Edwards, K.M. and Plotkin, S.A., (2018). Preface to the Seventh Edition. In Plotkin's Vaccines (Seventh Edition).2018; p:666.

3. Gowri, M. \& Missiriya, S., Knowledge and practice of school teachers on health care of school children. Int J Pharm Bio Sci. 2017; 8(1), 227-231.

4. Shrestha, R. M., Miyaguchi, M., Shibanuma, A., Khanal, A., Yasuoka, J. \& Jimba, M.A School Health Project Can Uplift the Health Status of School Children in Nepal. PloS one.2016; 11(11), e0166001.

5. The Health Service Executive of Ireland. Schools for Health in Ireland. Publication Date: July 2013/Review Date: October 2015 available on: https://www.healthpromotion.ie/hp-files/docs/ HPM00841.pdf. 2015; p:3.

6. Cheng, N.Y.I. and Wong, M.Y.E. Knowledge and Attitude of School Teachers towards Promoting Healthy Lifestyle to Students. Health. 2015. 7, 119126.

7. Hussein, A., Sheren, N. A., Fatah, K. Knowledge and Attitude of Teachers about Communicable Diseases in some of Primary Schools in Erbil kufa Journal for Nursing sciences.2012.2(2), p: 135141.

8. Faraj, R. K. \& Khalifa, M. F. Assessment of Science Teachers' Awareness towards Communicable Diseases Control in Baghdad City Primary Schools. nursing national Iraqi specility. 2014. 27(2), 7-16.

9. Sahebihagh, M. H., Hosseini, S. Z., Hosseinzadeh, M., Shamshirgaran, S. M. Knowledge, Attitude, and Practice of Teachers in Tabriz(Iran) Elementry Schools Regarding Child Abuse (2015-2016). International Journal of Medical Research \& Health Sciences, 2016, 5, 9S:336-343.

10. Htun, Y.M., Lwin, K.T., Nwe, N., Soe, K., Sein, T.T. Knowledge, attitude and reported practice of primary school teachers on specified school health activities in Danuphyu Township, Ayeyarwaddy Region, Myanmar. South East Asia Journal of Public Health.2013.3(1):24-29.

11. Ganpatrao, J. S. Knowledge and practices of school teacher regarding disaster management. International Journal of Health System and Disaster Management. 2014.Vol. 2,Issue 2. p:98-102. 